OPEN ACCESS

Edited by:

Vittorio Capozzi,

Italian National Research Council, Italy

Reviewed by:

Zhen Wu,

Ningbo University, China

Sandra M. Ruzal,

University of Buenos Aires, Argentina

*Correspondence:

Francesca Patrignan

francesca.patrignani@unibo.it

Specialty section: This article was submitted to

Food Microbiology,

a section of the journal

Frontiers in Microbiology

Received: 10 January 2021

Accepted: 22 April 2021

Published: 28 May 2021

Citation:

Braschi G, D'Alessandro $M$, Gottardi D, Siroli L, Patrignani F and

Lanciotti R (2021) Effects of

Sub-Lethal High Pressure

Homogenization Treatment on

the Adhesion Mechanisms and Stress

Response Genes in Lactobacillus

acidophilus 08

Front. Microbiol. 12:651711. doi: 10.3389/fmicb.2021.651711

\section{Effects of Sub-Lethal High Pressure Homogenization Treatment on the Adhesion Mechanisms and Stress Response Genes in Lactobacillus acidophilus 08}

\author{
Giacomo Braschi ${ }^{1}$, Margherita D'Alessandro ${ }^{1}$, Davide Gottardi ${ }^{1}$, Lorenzo Siroli ${ }^{1,2}$, \\ Francesca Patrignani ${ }^{1,2 *}$ and Rosalba Lanciotti ${ }^{1,2}$ \\ ${ }^{1}$ Department of Agricultural and Food Sciences, University of Bologna, Cesena, Italy, ${ }^{2}$ Interdepartmental Center \\ for Industrial Agri-Food Research, University of Bologna, Cesena, Italy
}

Cell surface hydrophobicity $(\mathrm{CSH})$ and adhesion are very important phenotypical traits for probiotics that confer them a competitive advantage for the resilience in the human gastrointestinal tract. This study was aimed to understand the effects over time of a $50 \mathrm{MPa}$ hyperbaric treatment on the surface properties of Lactobacillus acidophilus 08 including $\mathrm{CSH}$, autoaggregation, and in vitro adhesion (mucin layer and Caco-2 cells). Moreover, a link between the hurdle applied and the expression of genes involved in the general stress response (groEL and $c / p P$ ) and adhesion processes (efTu and s/pA) was evaluated. High pressure homogenization $(\mathrm{HPH})$ at $50 \mathrm{MPa}$ significantly increased the $\mathrm{CSH}$ percentage $(\mathrm{H} \%)$, autoaggregation and in vitro adhesion on mucin of $L$. acidophilus 08 cells compared with the untreated cells. Moreover, the hyperbaric hurdle induced an upregulation of the stress response genes groEL and ef-TU together with a down regulation of the c/pP and S-layer s/pA genes. Looking at the protein profile, $\mathrm{HPH}$ treatment showed an increase in the number or intensity of protein bands at high and low molecular weights.

\footnotetext{
Keywords: cell surface hydrophobicity, adhesion, Lactobacillus acidophilus 08 , high pressure homogenization, moonlight protein, stress response, chaperonin, probiotics
}

\section{INTRODUCTION}

Probiotics have become increasingly popular during the last decades as a result of the expanding scientific evidence that supports their beneficial effects on human health (FAO/WHO, 2001; Morelli and Capurso, 2012; Shewale et al., 2014). Most of the probiotic formulations contain lactobacilli, food-grade microorganisms widely applied in the food industry for their positive technological and health-promoting properties (Grosu-Tudor et al., 2016). Among them, Lactobacillus acidophilus is largely applied in the dairy sector and it is widely studied for its physiological, biochemical, genetic, and fermentative properties (Sanders and Klaenhammer, 2001; Weiss and Jespersen, 2010). Within this species, the probiotic L. acidophilus 08 (Burns et al., 2008), a strain already used as an adjunct for fresh cheeses and fermented milk preparations, can withstand very well cheesemaking and refrigerated storage conditions (Burns et al., 2008; Tabanelli et al., 2013). These technological 
characteristics, together with the functional ones, are fundamental when probiotics are meant to be incorporated in food. In fact, these beneficial microorganisms must be ingested at levels between $10^{8}$ and $10^{10} \mathrm{CFU} /$ day to induce positive effects on the consumers. For this reason, several studies focused on identifying technological strategies which aim to improve probiotics viability during food processing and subsequent storage (Patrignani and Lanciotti, 2016). Among these strategies, the non-thermal technology based on high pressure homogenization $(\mathrm{HPH})$ has already proved to enhance the survival of probiotic strains or to improve their overall functionality when treated in milk (Burns et al., 2008, 2015; Patrignani et al., 2009). Moreover, several studies showed that cell hydrophobicity, auto-aggregation, and in vitro resistance to simulated upper gastrointestinal tract were modulated in L. acidophilus 08 exposed to sub-lethal $\mathrm{HPH}$ treatments (50 MPa) (Tabanelli et al., 2013, 2014). In order to explain these changes, Tabanelli et al. (2015) proved that HPH is able to affect the outermost cellular stucture and induce a specific proteomic profile of the two probiotic strains Lacticaseibacillus paracasei A13 and L. acidophilus DRU, modulating in turns some of their technological and functional properties, including their ability to adhere and colonize the intestinal epithelium. For example, the higher interaction/adhesion observed of the L. paracasei A13 strain and intestinal epithelial cells upon hyperbaric treatment could be associated to cellular structure modifications (Tabanelli et al., 2012) involving the peptidoglycan structure, the different zwitterion character of the lipoteichoic acid (LTA), and surface proteins. Even the cell membrane, that contributes to separate microorganisms from the external environment, is considered one of the most susceptible targets of pressure and can respond in different ways to minimize sub-lethal stress (Serrazanetti et al., 2015). Changes in membrane composition are reflected in the modification of physical cell surface properties. According to the literature data, the presence of secondary cell wall polymers and adhesive proteins on the bacterial surface [i.e., mucin-binding proteins, fibronectin-binding proteins, surface layer proteins (Slps), surface layer associated proteins (SLAPs), and adhesion exoproteins] mediate the adhesion and immunomodulatory activities of $L$. acidophilus and other lactic acid bacteria (Palomino et al., 2016; Selle et al., 2017; Wang et al., 2018). For instance, the large amphiphilic interfacial polymer LTA plays pleiotropic roles in Gram-positive physiology and is a major immunomodulatory cell surface component. Even the S-layers proteins can act as a barrier against environmental hazards, control the transfer of nutrients and metabolites, maintain the cell shape, and promote surface recognition (Buck et al., 2005; Grosu-Tudor et al., 2016). However, SlpA, the major component of the S-layer in L. acidophilus, contributes to epithelial cell-bacteria interaction at the gut level and to the immune response modulation.

Although literature data are consistent in reporting the positive effects of sub-lethal HPH treatments on the probiotic features (i.e., hydrophobicity and autoaggregation) in a strain dependent way, little is known about the microbial gene expression upon this stress. Recently, Siroli et al. (2020) showed that $L$. paracasei A13 activated a series of reactions which aimed to control and stabilize membrane fluidity in response to $\mathrm{HPH}$ treatments inducing an upregulation of genes involved in fatty acids biosynthesis as an immediate response mechanism adopted by L. paracasei A13 to HPH. However, information is scarce following the application of $\mathrm{HPH}$ sublethal treatment on several stress response proteins, such as the chaperonins GroEL and DnaK, proteases ClpP, GroEL, and DnaK, which play a key role in several stress conditions (Frees et al., 2007; Weiss and Jespersen, 2010) and the genes involved in microbial cell adhesion in L. acidophilus.

Thus, in this framework, the present study investigated the effects of a sub-lethal $\mathrm{HPH}$ treatment $(50 \mathrm{MPa})$ on the different phenotypical traits involved in the adhesion phenomena processes like cell surface hydrophobicity (CSH), autoaggregation, and in vitro adhesion (both in mucins and Caco-2 cells) of L. acidophilus 08 , a probiotic strain commonly used in commercial functional dairy products. Structural modifications induced by the sub-lethal HPH treatments were observed by transmission electronic microscope. Moreover, the up or down regulation of genes involved in the general stress responses (groEL and $c l p P$ ) and adhesion processes (efTu and $\operatorname{slp} A$ ) were assessed, as well as the overall protein profile of the treated and untreated L. acidophilus 08 cells.

\section{MATERIALS AND METHODS}

\section{Bacterial Strain}

Lactobacillus acidophilus 08, a commercial probiotic strain isolated from dairy Argentinean dairy products, was stored at $-80^{\circ} \mathrm{C}$. Before the experiments, L. acidophilus 08 was cultured three times without stirring, for $24 \mathrm{~h}$ in de Man, Rogosa, and Sharpe (MRS) broth (Thermo Fisher Scientific, Milano, Italy) at $37^{\circ} \mathrm{C}$.

\section{High-Pressure Homogenization Treatments}

Lactobacillus acidophilus 08 cells after $18 \mathrm{~h}$ at $37^{\circ} \mathrm{C}$ of growth (early stationary phase cells) in MRS broth were subjected to $\mathrm{HPH}$ at $50 \mathrm{MPa}$ using a PANDA plus 2000 high-pressure homogenizer equipped with heat exchanger (Niro Soavi, Parma, Italy). Sample inlet temperature was $25^{\circ} \mathrm{C}$, while after treatment the sample temperature was approximately $30^{\circ} \mathrm{C}$. After the hyperbaric treatment, samples were taken for the gene expression and CSH assays as described below.

\section{Phenotypical Trials Cell Surface Hydrophobicity Kinetics}

The CSH of L. acidophilus 08 cell was evaluated as hydrophobicity percentage index $(\mathrm{H} \%)$ according to Vinderola and Reinheimer (2003), with some modification as suggested by Tabanelli et al. (2013).

The ability of the strain considered to adhere to n-hexadecane and its evolution during $2 \mathrm{~h}$ was tested in relation to the HPH 
treatment applied (50 MPa). The $\mathrm{H} \%$ index was calculated with the formula:

$$
\mathrm{H} \%=\left(\frac{\mathrm{A} 0-\mathrm{At}}{\mathrm{A} 0}\right) * 100
$$

where At represents the absorbance at $560 \mathrm{~nm}$ after $1 \mathrm{~h}$ of incubation at $37^{\circ} \mathrm{C}$, while A0 represents the initial absorbance (Vinderola and Reinheimer, 2003; Tabanelli et al., 2013). After the $\mathrm{HPH}$ treatment at $50 \mathrm{MPa}, L$. acidophilus 08 cell suspension was centrifuged at $8,000 \mathrm{rpm}$ for $10 \mathrm{~min}$ at $4^{\circ} \mathrm{C}$, washed two times with $\mathrm{NaCl} 0.9 \%$ isotonic solution, and then, the cell optical density (OD) at $560 \mathrm{~nm}$ was adjusted with the same solution to 1 .

\section{Autoaggregation}

Autoaggregation assay was performed as described by Valeriano et al. (2014). After HPH treatment, the treated and untreated cells were harvested by centrifugation at 3,800 rpm for $10 \mathrm{~min}$ at $10^{\circ} \mathrm{C}$, washed twice, and resuspended in sterile PBS to obtain approximately $10^{8-9} \mathrm{CFU} / \mathrm{mL}$ viable counts. Cell suspensions $(40 \mathrm{~mL})$ were mixed by vortexing for $10 \mathrm{~s}$ and, autoaggregation was determined after three and $6 \mathrm{~h}$ of incubation at room temperature. To measure the autoaggregation, $100 \mu \mathrm{L}$ of the upper suspension were transferred to $900 \mu \mathrm{L}$ of PBS and the absorbance (A) was measured at $600 \mathrm{~nm}$. The autoaggregation percentage was expressed as:

$$
\% \text { Autoaggregation }=1-\left(\frac{A_{t}}{A_{0}}\right) * 100
$$

where At represents the absorbance after 3 and $6 \mathrm{~h}$ of incubation, while $\mathrm{A} 0$ is the absorbance at $\mathrm{t} 0$.

\section{Adhesion Assay to Mucins}

The assessment of microbial adhesion to mucins was performed following the protocol of Valeriano et al. (2014) with some modifications. 96-well polystyrene microtiter plates (Sigma, Bornem) were used to obtain a high-throughput adhesion assay. Mucous gel that covers the intestinal epithelium was simulated by mixing porcine mucin type II (Sigma) (5\%, w/v) and agar $(0.8 \%)$ resuspended in phosphate-buffered saline $(\mathrm{PBS}, \mathrm{pH}=7.0)$ according to Van den Abbeele et al. (2009). Mucin agar was sterilized by autoclaving at $121^{\circ} \mathrm{C}$ for $15 \mathrm{~min}$ and, then, $100 \mu \mathrm{l}$ were added in each well. Approximately $100 \mu \mathrm{l}$ of bacterial suspension $\left(\sim 10^{8-9} \mathrm{CFU} / \mathrm{ml}\right)$ were washed, suspended in PBS buffer ( $\mathrm{pH} 7.0$ ), and added to the wells. Plates were incubated at $37^{\circ} \mathrm{C}$ for $1 \mathrm{~h}$. After incubation, wells were washed five times with $200-\mu \mathrm{l}$ sterile citrate buffer ( $\mathrm{pH}$ 5.9) to remove unbound bacteria. Another $200 \mu \mathrm{l}$ of $0.5 \%(\mathrm{v} / \mathrm{v})$ Triton X-100 was then added to isolate the attached bacteria. The viable cell count, expressed as $\mathrm{CFU} / \mathrm{ml}$, was determined in all cases by plating on the MRS media. Each assay was performed in quadruplicate. Percentage adhesion was calculated as follows (Collado et al., 2008):

$$
\% \text { Relative Adhesion }=\left(\frac{\mathrm{CFU} / \mathrm{mL} \text { after adhesion }}{\mathrm{CFU} / \mathrm{mL} \text { before adhesion }}\right) * 100
$$

The assay was performed with HPH treated cells incubated for 60,90 , and $120 \mathrm{~min}$ and $24 \mathrm{~h}$ before the adhesion test, and untreated L. acidophilus 08 and Lactobacillus rhamnosus GG as controls.

\section{Adhesion Assay to Caco-2 Cells}

In order to describe the ability of L. acidophilus 08 , treated at $50 \mathrm{MPa}$, to adhere to the intestinal epithelium, Caco- 2 cell line was used. This cell line is derived from human colorectal adenocarcinoma and presents the ability to differentiate into cells with many properties typical of enterocytes (Lea, 2015). Caco-2 cells were routinely grown in DMEM high glucose medium (Sigma, Milan, Italy) with the addition of $2 \mathrm{mM}$ L-glutamine (Sigma, Milan, Italy) and $20 \% \mathrm{v} / \mathrm{v}$ Bovine Fetal Serum (Sigma, Milan, Italy) in flasks for cell cultures (Corning, $\mathrm{NY}$, United States), at $37^{\circ} \mathrm{C}$ with $5 \% \mathrm{CO}_{2}$. To obtain the differentiated Caco-2 cultures, the cells were inoculated at a density of $10^{5}$ cells $/ \mathrm{cm}^{2}$ and kept in culture for 21 days, changing the culture medium every 3-4 days. For adhesion tests, Caco-2 cells were inoculated on sterile glass coverslips in six-wells plates and grown until differentiated. Cells were then incubated with exponentially growing lactobacilli cells by applying a 1:400 ratio, at $37^{\circ} \mathrm{C}$ with $5 \% \mathrm{CO}_{2}$ for $1 \mathrm{~h}$, and washed twice with PBS to remove the non-adherent lactobacilli. Samples were then fixed with methanol for 10 min and stained with Giemsa 10\% (Sigma, Milan, Italy) for eight min. Afterward, samples were washed three times with PBS, and then air dried and observed by an optical microscope $(1000 \times$ magnification). Also, the untreated cells of L. acidophilus 08 were tested. Adhesion to Caco- 2 cells was evaluated by counting the number of adherent Lactobacillus cells to Caco- 2 cells, considering at least 200 Caco- 2 cells.

\section{Transmission Electronic Microscope}

Transmission electron microscopy (TEM) was used to investigate the morphological changes caused by the HPH treatment. Ten milliliters of the control samples and the HPH-treated samples were centrifuged $(8,000 \mathrm{~g}, 10 \mathrm{~min})$ and the pelleted cells were fixed by suspending them in $2.5 \%$ glutaraldehyde (in $0.1 \mathrm{M}$ PBS buffer, $\mathrm{pH} 7$ ). These samples were stored at $4^{\circ} \mathrm{C}$ for $2 \mathrm{~h}$. After aldehyde fixation, the samples were prepared according to Bury et al. (2001). The post-fixed cells were washed using the same buffer, and then, they were dehydrated for $15 \mathrm{~min}$ using the following series of ethanol solutions: 50, 75, 90, and 100\%. The dehydrated cells were infiltrated with increasing concentrations of Spurrresin (Agar Scientific, Stansted, Essex, United Kingdom) over $24 \mathrm{~h}$. Polymerization of the resin was achieved by heating the samples in an oven at $65^{\circ} \mathrm{C}$ for $18 \mathrm{~h}$. These sections $(\sim 90 \mathrm{~nm}$ thick) were placed on carbon-coated Form var-covered 300mesh copper grids for approximately $15 \mathrm{~min}$, rinsed using 20 drops of distilled water, negatively stained using 6-7 drops of $2 \%$ aqueous uranyl acetate, and then, examined using a Philips CM10 transmission electron microscope.

\section{Reverse Transcription Quantitative PCR}

Lactobacillus acidophilus 08 RNA was extracted using the MasterPure $^{\mathrm{TM}}$ Complete DNA and RNA Purification (Lucigen). The yield and the purity of each extraction was determined by measuring the absorbance at $260_{\mathrm{nm}}$ and $280_{\mathrm{nm}}$ using a BioDrop $\mu$ LITE (BioDrop, Milan, Italy). For all the samples, the yields were about $700 \mathrm{ng} / \mu \mathrm{L}$ and only samples with a ratio $260_{\mathrm{nm}} / 280_{\mathrm{nm}}$ between 1.9 and 2.1 were used for the reverse transcription reaction. 
The reverse transcription into cDNA was performed using the Reverse Transcription System Kit (Promega, Wisconsin, WI, United States) following the manufacturer's instruction. Before the real time assays, samples were properly diluted in DNAse/RNAse free water (Promega, Wisconsin, WI, United States) to reach a final concentration of $5 \mathrm{ng} / \mu \mathrm{L}$.

Reverse transcription quantitative PCR (RT-qPCRs) were performed using a Rotor gene 6000 thermal cycler (Corbett Life Science, Mortlake, NSW, Australia). The list of genes and their function are reported in Table 1 . The best RT-qPCR reaction conditions for each primer stet were investigated by end point PCRs using L. acidophilus 08 genomic DNA as a template. Different final concentrations of $\mathrm{MgCl}_{2}(2.00,3.00,4.00 \mathrm{mM})$ and annealing temperatures (AT) were tested. Amplification quality was verified by gel electrophoresis using $1.5 \%$ agarose gels (data not showed).

The RT-qPCR reaction mixture $(10 \mu \mathrm{L})$ included $5 \mathrm{ng}$ of cDNA, $10 \mu \mathrm{L}$ of SsoFast EvaGreen Supermix (Bio-Rad), $500 \mathrm{nM}$ each primer, and $8 \mu \mathrm{L}$ DNAse/RNAse free water (Promega, Wisconsin, WI, United States). Each reaction was performed in triplicate.

For each gene, a threshold line and a quantitative cycle (Cq) were determined using the Rotor-Gene series software (Qiagen Inc., Ontario, ON, Canada). For each primer pair, the amplification efficiency (E) was calculated as described by Pfaffl (2001) using the formula:

$$
\mathrm{E}=10^{(-1 / \text { slope })}
$$

and genomic L. acidophilus 08 DNA standard curves built using five different DNA concentrations.

\section{Relative Gene Expression Analysis}

The relative gene expressions indexes (RGE indexes) were determined according to the MIQE guidelines (Bustin et al., 2009) using the mathematical model proposed by Pfaffl (2001). Based on literature, the performance of two Reference Genes (RGs) were tested in the experimental condition: 23S RNA and gadpH. The gene expression stability of the two candidates RGs were analyzed using the BestKeeper@ tool program
(Pfaffl et al., 2004), and on the basis of the Pearson correlation index, 23S RNA was chosen.

\section{L. acidophilus 08 SDS-PAGE Protein Analysis}

Total L. acidophilus 08 proteins were extracted from the $\mathrm{HPH}$ treated and untreated cells according to Palomino et al. (2016) with some modifications. From each sample, $20 \mathrm{~mL}$ of L. acidophilus 08 suspension was collected and washed with sterile PBS ( $\mathrm{pH} 7.0)$ by refrigerated centrifugation $\left(10^{\circ} \mathrm{C}\right)$ at $3,800 \mathrm{rpm}$ for $10 \mathrm{~min}$. Harvested cells were diluted again in PBS buffer until an OD $600_{\mathrm{nm}}=1.0$ was reached. Concentrated cell suspension was diluted 1:1 in loading buffer [20\% glycerol, $4 \%$ sodium dodecyl sulfate (SDS), $1 \% \beta$-mercaptoethanol, Tris- $\mathrm{HCl}$ $0.15 \mathrm{M}$ ] and total proteins were extracted by heating at $100^{\circ} \mathrm{C}$ for $5 \mathrm{~min}$. After, the incubation protein samples were analyzed by electrophoresis on 8-16\% SDS-PAGE gels (Biorad, Milan Italy). Electrophoresis was performed at a constant voltage of $100 \mathrm{~V}$ for $30 \mathrm{~min}$ and then at $200 \mathrm{~V}$ until the run was completed.

\section{Statistical Analysis}

Data were processed using the STATISTICA 8 software tool (Version 8.0; Statsoft., Tulsa, OK, United States).

The CSH, cell loads, and relative gene expression (RGE) detected in relation to the $50 \mathrm{MPa}$ homogenization pressure applied and to the frame time considered $(2 \mathrm{~h})$ were considered significant $(p<0.05)$ on the basis of the ANOVA and TUKEY HSD post hoc test, while adhesion to mucus and autoaggregation were significant $(p<0.05)$ on the base of the $t$-test. For both tests, the untreated control cells were considered the control condition.

\section{RESULTS}

\section{Effects of HPH at $50 \mathrm{MPa}$ on L. acidophilus 08 Cell Viability and Cell Surface Hydrophobicity}

In Figure 1, the changes in CSH of L. acidophilus $08(\mathrm{H} \%)$ after the homogenization treatment at $50 \mathrm{MPa}$ are reported.

TABLE 1 | List of genes and primers and protein functions considered in this trial.

\begin{tabular}{|c|c|c|c|c|}
\hline Gene & Primer $5^{\prime}>3^{\prime}$ & Protein function & $\mathrm{Ta}^{1}\left({ }^{\circ} \mathrm{C}\right)$ & References \\
\hline \multirow[t]{2}{*}{ groEL } & F: GCTGTTAAGGCACCTGGTITTG & Molecular chaperonins & 60 & Weiss and Jespersen, 2010 \\
\hline & R: AAGGGCTGCAATGTCTTCAAG & & & \\
\hline \multirow[t]{2}{*}{ efTU } & F: GGTGCTATCTTAGTTGTTGC & Translational elongational factor TU & 55 & Ramiah et al., 2009 \\
\hline & R: CAACCAAGTCGATCAATTCT & & & \\
\hline \multirow[t]{2}{*}{$\operatorname{s} / p A$} & F: GCACAACGCATACTACTACG & S-layer protein A & 55 & Ramiah et al., 2009 \\
\hline & R: CTTGTCAACAGCCTTACCGT & & & \\
\hline \multirow[t]{2}{*}{$c / p P$} & F: GCAATCGGTATGGCAGCAT & ATP-dependent Clp protease & 60 & Weiss and Jespersen, 2010 \\
\hline & R: ACGCTTACCCTITGTACCACTTG & & & \\
\hline \multirow[t]{2}{*}{$\operatorname{gadpH}(R G)$} & F: CTATCGTTTACTCAGTAAACCAAGA & Glyceraldehyde-3-phosphate dehydrogenase & 55 & Ramiah et al., 2009 \\
\hline & R: CGTGGATAGTAGTCATAGTACCAAC & & & \\
\hline \multirow[t]{2}{*}{ 23S rRNA (RG) } & F: TGTCAGGTGGGCAGTITGAC & & 60 & Weiss and Jespersen, 2010 \\
\hline & R: TTGAGCGCCTCCGTTACAC & & & \\
\hline
\end{tabular}

${ }^{1}$ Annealing temperature $\left({ }^{\circ} \mathrm{C}\right)$. 
The $\mathrm{H} \%$ of treated L. acidophilus 08 increased up to $18.4 \%$ after $5 \mathrm{~min}$ of incubation, then it decreased in the following $60 \mathrm{~min}$, and it increased again during the remaining period considered (120 min). On the contrary, the $\mathrm{H} \%$ of untreated cell decreased from 10 to $5 \%$ over time (Figure 1). The increased hydrophobicity observed in the treated samples was not associated with a reduction of $L$. acidophilus 08 viability. In fact, as shown in Table 2 , no significant loss of cell viability $(p<0.05)$ (Log CFU/mL) was observed upon $\mathrm{HPH}$ treatment within the following $120 \mathrm{~min}$ of incubation.

\section{Effects of HPH at $50 \mathrm{MPa}$ on in vitro Adhesion of $L$. acidophilus 08 in Mucin and Caco-2 Cells}

The $\mathrm{HPH}$ at $50 \mathrm{MPa}$ increased the mucin adhesion properties of L. acidophilus 08 (Figure 2). In fact, while the control had a relative adhesion ranging between 0.38 and $1.66 \%$, in $\mathrm{HPH}$ treated cells, however, this value increased up to 2.22 and $5.13 \%$ after 60 and $90 \mathrm{~min}$, respectively, and then, it reduced to $2.73 \%$ at $120 \mathrm{~min}$ (Figure 2). The same trial was performed assessing the adhesion of the treated and untreated bacteria on Caco2 cells. In this case, only the time point that showed the best mucin adhesion (90 min) was tested. However, no significant differences were observed $(9.49 \pm 4.88$ and $7.42 \pm 2.48$ adherent L. acidophilus 08/Caco-2 cells for untreated and HPH-treated samples, respectively).

\section{Effects of HPH at $50 \mathrm{MPa}$ on Autoaggregation of $L$. acidophilus 08}

In Figure 3, the autoaggregation kinetic over time (90-360 min) of the treated and untreated L. acidophilus 08 is reported.
Significant differences $(p<0.05)$ between the two samples were obtained after 90 and $120 \mathrm{~min}$, with a higher autoaggregation in the HPH-treated cells that reached values of $25.45 \%$ after $120 \mathrm{~min}$. On the contrary, no differences were observed after 300 and $360 \mathrm{~min}$ (Figure 3).

\section{Effect of HPH at $50 \mathrm{MPa}$ on the Outermost Cellular Structure of} L. acidophilus 08

Figures 4A-C show the TEM images of the treated and untreated cells of $L$. acidophilus 08 , a species commonly characterized by the presence of an S-layer in the cell envelope. Immediately after the treatment, HPH impacted on the outermost cellular structures. In fact, the continuous and tinny S-layer of untreated L. acidophilus 08 (Figure 4A) was modified generating a discontinuous and fragmented surface in the HPH-treated cells (Figure 4B). Moreover, some sublethal damages were observed in the cell wall due to the mechanical stress imposed (Figure 4C).

\section{Effects of $\mathrm{HPH}$ at $50 \mathrm{MPa}$ on the Adhesion and Stress Response Genes of L. acidophilus 08}

Figure 5 illustrates the expression of adhesion (efTU and $\operatorname{slp} A$ ) and acid stress response ( $g r o E L$ and $c l p P$ ) related genes in the $120 \mathrm{~min}$ that followed the hyperbaric treatment (Figure 5). groEL and efTU were upregulated, while $c l p P$ and $\operatorname{slp} A$ were downregulated (Figure 6). In particular, groEL and ef-TU showed a similar expression trend within the first $5 \mathrm{~min}$, with a 1.5 and 2fold increase $(p<0.05)$, respectively. Then, the gene induction wave reached a maximum of fourfold increase between 30 (ef$T U)$ and 90 (groEL) min and eventually decreased to values that

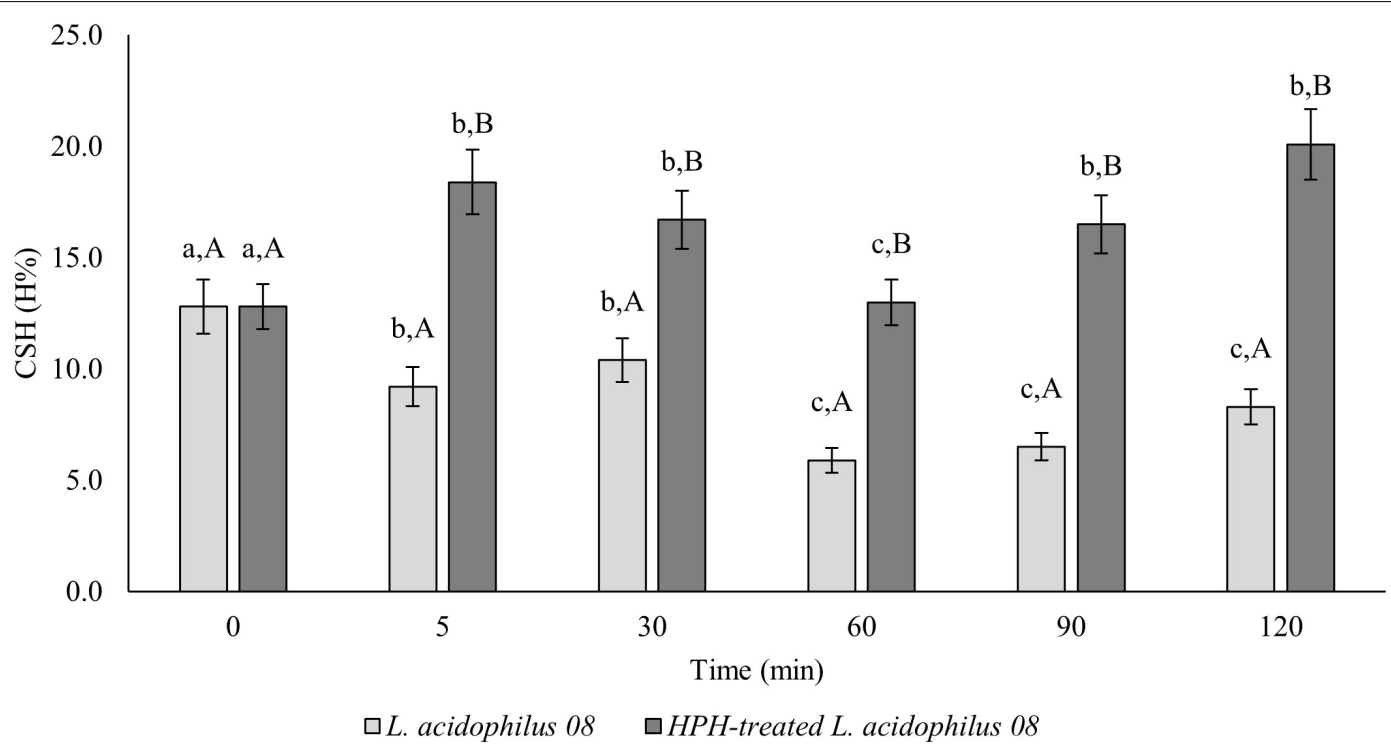

FIGURE 1 | Lactobacillus acidophilus 08 cell surface hydrophobicity $(\mathrm{CSH})(\mathrm{H} \%)$ of the untreated $(\mathrm{L}$. acidophilus 08$)$ and treated cells at $50 \mathrm{MPa}(\mathrm{HPH}$-treated $L$. acidophilus 08). The results are the average of three independent replicates $(n=3)$. Error bars indicate the SD. Among the series, different letters indicate the samples that are significantly different $(p<0.05)$. Different lowercase letters indicate the significant differences for a considered sample during the frame time considered (0-120 min), while capital letters indicate the significant differences at the considered time differences between samples (untreated control and treated). 
TABLE 2 | Viability of the untreated (control) and treated (HPH at $50 \mathrm{MPa})$ cells of L. acidophilus 08 over time (0-120 min).

\begin{tabular}{lcc}
\hline & \multicolumn{2}{c}{ Log $\mathbf{C F U / \mathbf { m L }}$} \\
\cline { 2 - 3 } Time (min) & Untreated control & $\mathbf{5 0} \mathbf{~ M P a}$ \\
\hline 0 & $8.53^{\mathrm{a}, \mathrm{A}} \pm 0.23$ & $8.85^{\mathrm{a}, \mathrm{A}} \pm 0.18$ \\
5 & $8.69^{\mathrm{a}, \mathrm{A}} \pm 0.47$ & $8.29^{\mathrm{a}, \mathrm{A}} \pm 0.26$ \\
30 & $8.44^{\mathrm{a}, \mathrm{A}} \pm 0.38$ & $8.41^{\mathrm{a}, \mathrm{A}} \pm 0.42$ \\
60 & $7.74^{\mathrm{a}, \mathrm{A}} \pm 0.31$ & $7.99^{\mathrm{a}, \mathrm{A}} \pm 0.24$ \\
90 & $8.25^{\mathrm{a}, \mathrm{A}} \pm 0.38$ & $8.37^{\mathrm{a}, \mathrm{A}} \pm 0.45$ \\
120 & $8.21^{\mathrm{a}, \mathrm{A}} \pm 0.31$ & $8.13^{\mathrm{a}, \mathrm{A}} \pm 0.30$ \\
\hline
\end{tabular}

Different lowercase letters indicate significant differences among control and treated samples. For each considered sample, different capital letters indicate significant differences along the time.

are close to the initial ones at $120 \mathrm{~min}(p<0.05)$ (Figure 2). On the contrary, homogenization at $50 \mathrm{MPa}$ significantly $(p<0.05)$ reduced the expression of $\operatorname{clp} P$ and $\operatorname{slp} A$ in the $2 \mathrm{~h}$ following the treatment. A half-fold reduction in $c l p P$ expression was reached after $30 \mathrm{~min}$ from the treatment and the down regulation persisted for $2 \mathrm{~h}$ (Figure 5). A similar behavior was observed for $\operatorname{slp} A$ (Figure 5).

\section{Effects of HPH at $50 \mathrm{MPa}$ on Whole Cell Proteins of $L$. acidophilus 08}

The separation of the proteins extracted from $L$. acidophilus 08 after $\mathrm{HPH}$ at $50 \mathrm{MPa}$ and during the next $24 \mathrm{~h}$ was carried out by the SDS-PAGE (Figure 6). Proteins of the untreated L. acidophilus 08 were taken as the control. Protein bands were estimated by the comparison with the molecular mass standards (20-250 KDa). Compared with the control, hyperbaric treatment samples showed a higher number of proteins bands (and in some cases more intense), having low and high molecular weights, even after $90 \mathrm{~min}$ from the hurdle. This effect was kept in the subsequent $24 \mathrm{~h}$ (Figure 6).

\section{DISCUSSION}

In accordance with the literature, sub-lethal levels of $\mathrm{HPH}$ represent a useful tool to increase the probiotic features in a strain dependent manner. In the present research, the hyperbaric treatment performed at $50 \mathrm{MPa}$ modulated the phenotypical cell surface traits of L. acidophilus 08 without effecting its viability. In fact, $\mathrm{HPH}$ increased the CSH and autoaggregation over time. Compared to the untreated bacteria, HPH treated cells increased their CSH up to $20 \%$ for the entire 120 min considered, while autoaggregation differences were observed only up to $90 \mathrm{~min}$ from the start of the treatment. Regarding the adhesion assays tested, no differences were observed in the Caco- 2 cells. However, this result could have been affected by the single time point tested and the fact that Caco-2 are non-mucus producing cells (Gagnon et al., 2013). In fact, on the trial performed on a mucin layer, the treated bacteria showed an improved adhesion compared with the untreated ones (5.13 and $0.76 \%$, respectively, after $90 \mathrm{~min}$ from the hyperbaric hurdle). The collected data seem to prove that the response of L. acidophilus 08 to $\mathrm{HPH}$ is related to a modulation of its adhesion during a timeframe that goes from 60 to 120 min upon the treatment. These results can be considered a further advance compared with those described by Tabanelli et al. (2013) where hydrophobicity and autoaggregation were evaluated only immediately after $\mathrm{HPH}$ treatment. However, the differences in the two studies concerning the initial values of cell hydrophobicity and autoaggregation could be explained by the different media applied and cell growth stage. In fact, according to Klotz et al. (2017), the S-layer of L. acidophilus changes between the logarithmic and early stationary phases. Moreover, preculturing and inoculating methods could have a strong impact on cell behavior in relation to the experimental conditions applied (Kragh et al., 2018). TEM results were consistent with the findings of Tabanelli et al. (2015) regarding L. acidophilus DRU treated with HPH. In fact, the hurdle generated a discontinuous and fragmented cell surface. In the present study, sublethal damages of the cell wall due to the mechanical stress imposed were also observed. However, as already reported by Tabanelli et al. (2013), HPH did not decrease L. acidophilus 08 viability. The barotolerance of lactic acid bacteria such as Lactiplantibacillus plantarum subsp. plantarum, L. paracasei A13, and L. acidophilus Dru was already described by Lanciotti et al. (2007) and Tabanelli et al. (2013) using sub-lethal pressure. Even a higher pressure $(130 \mathrm{MPa})$ showed a scarce reduction in the viability of Lactobacillus helveticus and L. plantarum subsp. plantarum strains (Vannini et al., 2004) confirming this barotolerance.

The comprehension of the genetic mechanisms regulating the $\mathrm{CSH}$ is very important when studying probiotics since they can be correlated with the microbial capacity to adhere and, to some extent, colonize the intestinal epithelium, offering a competitive advantage to the selected strain (Schillinger et al., 2005). The data regarding gene expression suggested that the hyperbaric treatment was able to specifically modulate groEL and $c l p P$, which are both associated with the general stress response mechanisms. groEL codes for a cytoplasmic chaperonin protein (GroEL) and it is widely conserved among microbial species. Together with GroES and DnaK, GroEL is part of the repair complex for the folding of denatured polypeptides, and it is involved in many stress responses (Weiss and Jespersen, 2010; Hernández-Alcántara et al., 2018) such as the exposure to acids and bases, high saline concentrations, ethanol, oxygen, and heat (Hartl, 1996; Wickner et al., 1999; Saibil, 2008). In fact, during these conditions, chaperonin proteins are expressed and they revert the denaturation of unfolded polypeptides (Weiss and Jespersen, 2010; Mbye et al., 2020). When chaperonins fail to fold the damaged proteins, the molecular scavenger ATP-dependent Clp protease acts in degrading the damaged proteins. In our experiment, the $\mathrm{HPH}$ treatment produced a significant overexpression of groEL that was maintained for $90 \mathrm{~min}$, after that, it started to decline going back to the starting level.

Compared to groEL, the protease gene $c l p P$ showed an opposite response. In fact, the $\mathrm{HPH}$ treatment reduced its expression during the following 120 min of incubation. Thus, this may indicate that the upregulation of groEL pass through an alternative induction pattern not associated with the general 


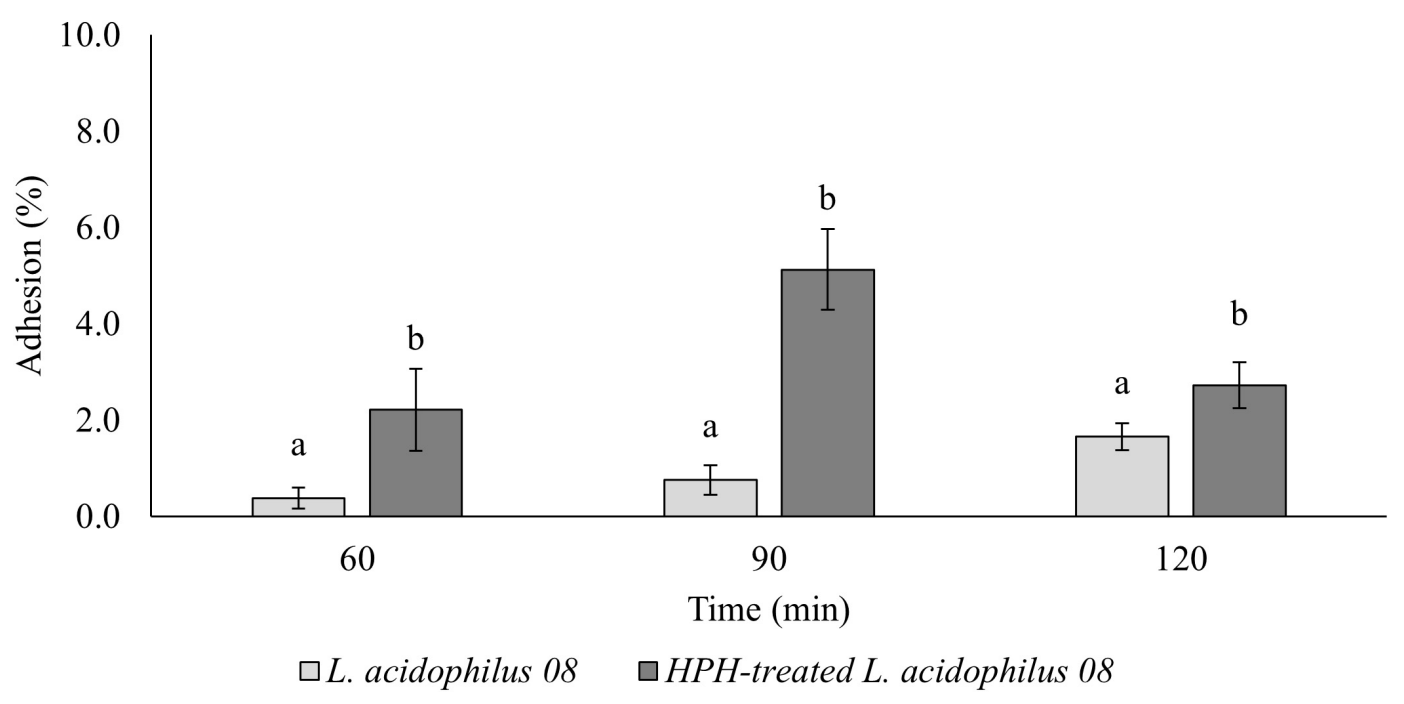

FIGURE 2 | Lactobacillus acidophilus 08 percentage adhesion values of the untreated (control) and treated (HPH at $50 \mathrm{MPa})$ cells over time (60-120 min). Relative adhesion was calculated on the base of CFU/mL before and after the adhesion assay. The results are the average of four independent replicates $(n=4)$. Error bars indicate the SD. Different lowercase letters indicate the significant differences ( $t$-test; $p<0.05)$ for a considered sample during the frame time considered (120 min).

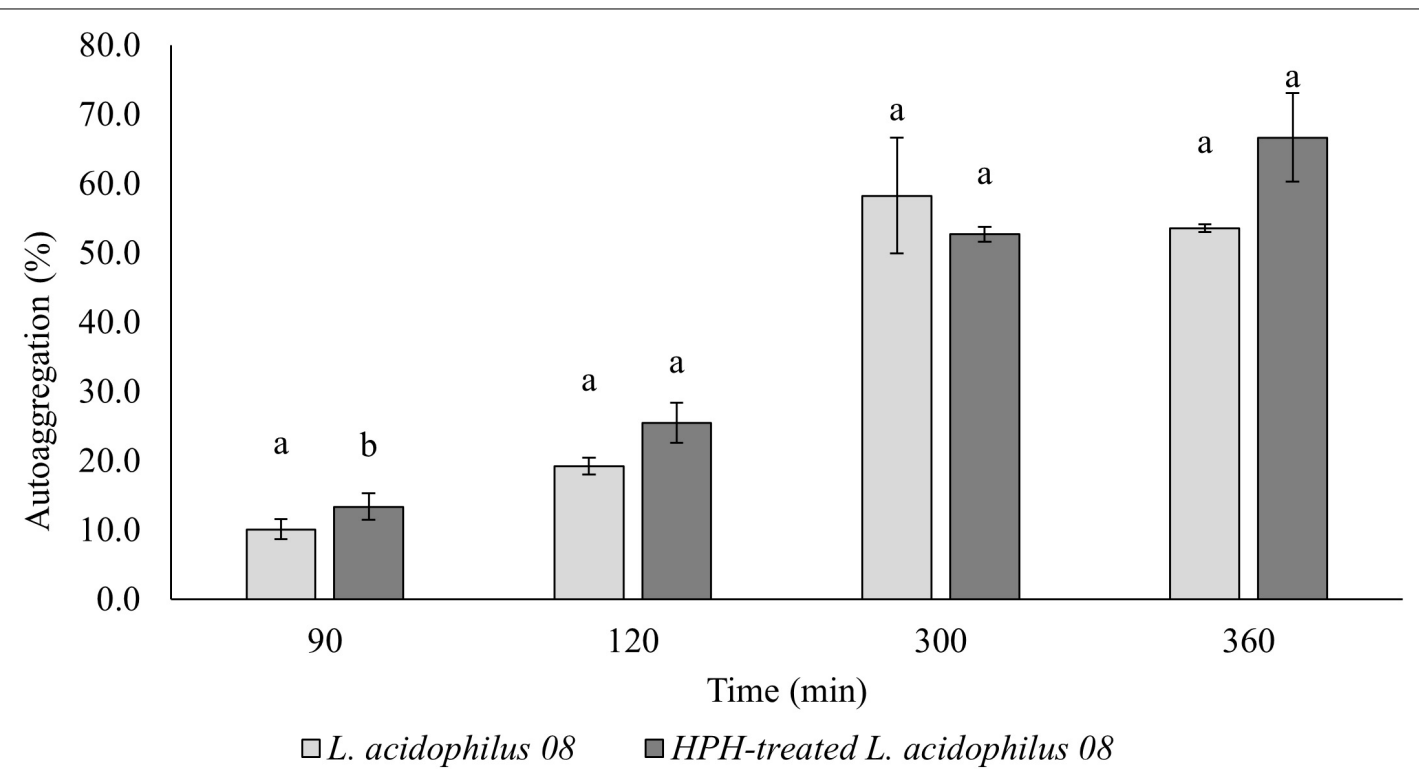

FIGURE 3 | Lactobacillus acidophilus 08 percentage autoaggregation values of the untreated (control) and treated (HPH-treated $L$. acidophilus 08) cells over time (90-360 min). Autoaggregation was calculated on the base of optical density (OD) at $\lambda=600_{\mathrm{nm}}$ before and after incubation from HPH at $50 \mathrm{MPa}$ treatments. The results are the average of three independent replicates $(n=3)$. Error bars indicate the SD. Different lowercase letters indicate significant differences $(t$-test; $p<0.05)$ for a considered sample during the frame time considered.

stress response. The data of the present research are partially in agreement with those found by Weiss and Jespersen (2010) on L. acidophilus NCFM during a gastrointestinal simulated digestion where the gastric conditions had a significant inducive effect on groEL and a moderate impact on $c l p P$. This suggests that the HPH treatment may lead to a gene expression in L. acidophilus 08 like the one induced by acid stress.

Although GroEL chaperonin is predominantly intracellular (Gupta, 1995), some authors have identified the presence of this protein on the cell surface of different probiotics and pathogens (Kainulainen and Korhonen, 2014) where it becomes part of the secretome. This complex gives the strains an advantage for ecological niche colonization. Moreover, other studies have suggested that groEL has a moonlight behavior (Kainulainen and Korhonen, 2014; Amblee and Jeffery, 2015; Jeffery, 2019), that is, the capability to perform more than one biological function, including adhesion (Kainulainen and Korhonen, 2014). As adhesine like protein, groEL can promote cell adhesion 

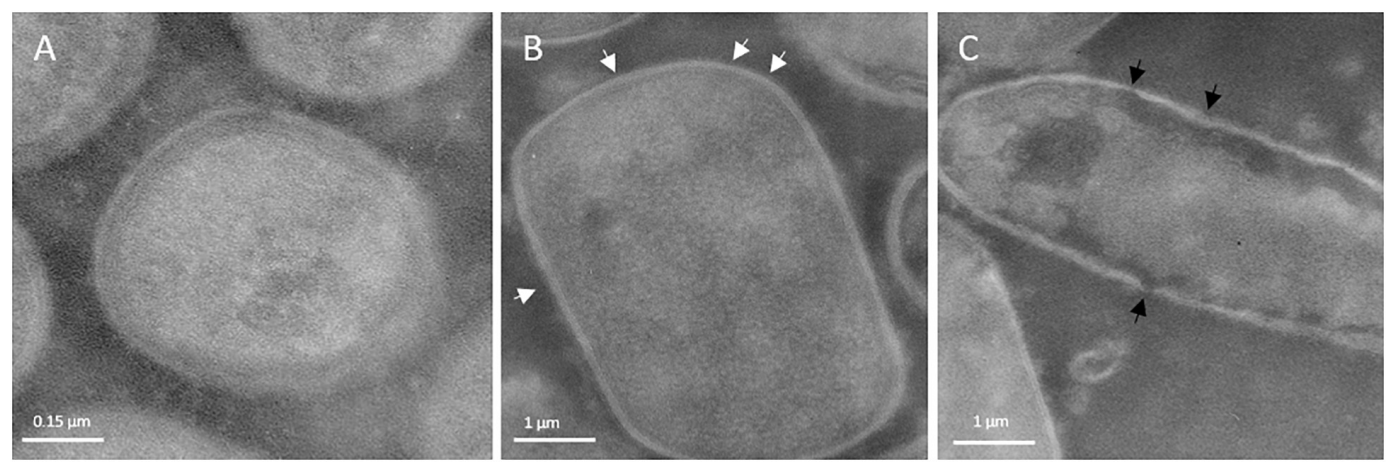

FIGURE 4 | Transmission electron micrographs of Lactobacillus acidophilus 08: untreated control (A); 50 MPa HPH treated cells (B,C). White arrows indicate discontinuous and fragmented surface; black arrows indicate cell wall sublethal damages. Magnification:52,000×.

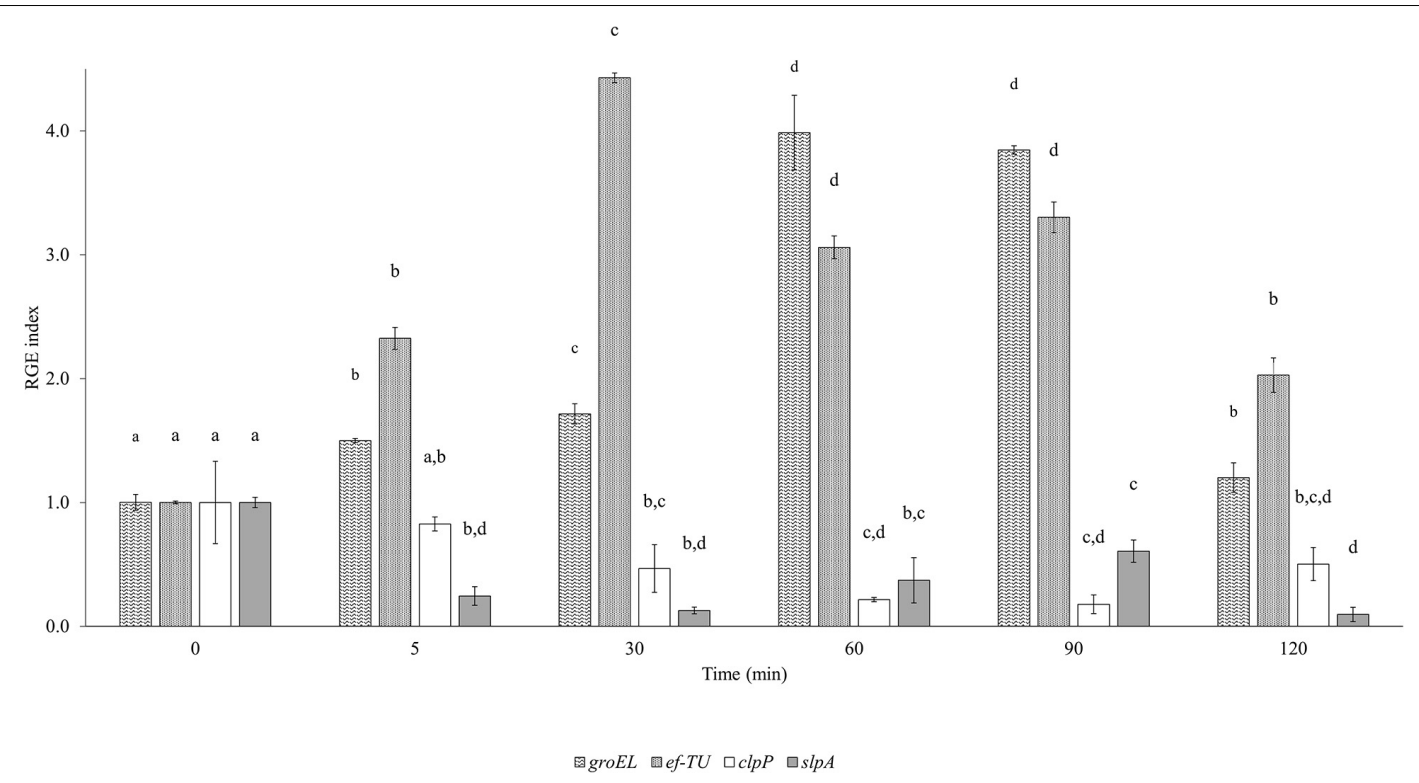

FIGURE 5 | Evolution of the Relative Gene Expression (RGE) index of Lactobacillus acidophilus 08 groEL (60 kDa chaperonin), ef-TU (elongation factor-TU), clpP (ATP-dependent Clp protease proteolytic subunit), and slpA (S-layer porotein A) genes after high pressure homogenization at 50 MPa using 235 RNA as the reference gene. Results are the mean of three independent replicates $(n=3)$ collected in a time frame of $0-120$ min. Error bars indicate the SD. Different letters are referred to the significant differences $(p<0.05)$ of the RGE of each gene during the frame time considered.

to mucus and epithelial cells, stimulate cytokine production, and inhibit enteropathogen adhesion to the host cell surface (Bergonzelli et al., 2006; Ramiah et al., 2008; Sánchez et al., 2009; Spurbeck and Arvidson, 2012; Sun et al., 2016; Peng et al., 2018). As reported by literature, the elongation factor-Tu (EF$\mathrm{Tu}$ ) should also have a moonlight behavior. In fact, other than functioning as a G-protein that facilitates the correct transfer of aminoacyl-tRNA to ribosomes during protein synthesis (Gaucher et al., 2001), EF-Tu can have an adhesion-like function (Granato et al., 2004; Amblee and Jeffery, 2015; Jeffery, 2019). Like GroEL, EF-Tu enhanced the adhesion of Lactobacillus johnsonii NCC 533 (La1) to the intestinal mucosa (Granato et al., 2004; Bergonzelli et al., 2006). In our study, ef-TU was induced by the sublethal $\mathrm{HPH}$ treatment and the pattern reflected the one observed for groEL, with the maximal expression level reached after
60-90 min. Moreover, Ramiah et al. (2009) found that simulated gastro duodenal environment (MRS broth supplemented with mucine, bile salt, and pancreatin) induced 40-fold the expression of the efTU gene in L. acidophilus ATCC 4356. This may suggest that $\mathrm{HPH}$ treatment had a similar impact on L. acidophilus 08 .

Although GroEL and EF-Tu are recognized for their moonlight effect, it cannot be inferred that their increased gene expression upon sublethal HPH treatment also determines a better adhesion. For sure, their increase is a response to stress conditions. In fact, during the passage through the homogenizing valve, millisecond increases of temperature and a rise in gas partition into cytoplasmic membranes generated a marked oxidative stress for the cells that can be counteracted more or less effectively, depending on the microbial species, strains, and protocols applied (Siroli et al., 2020). Although, this is 


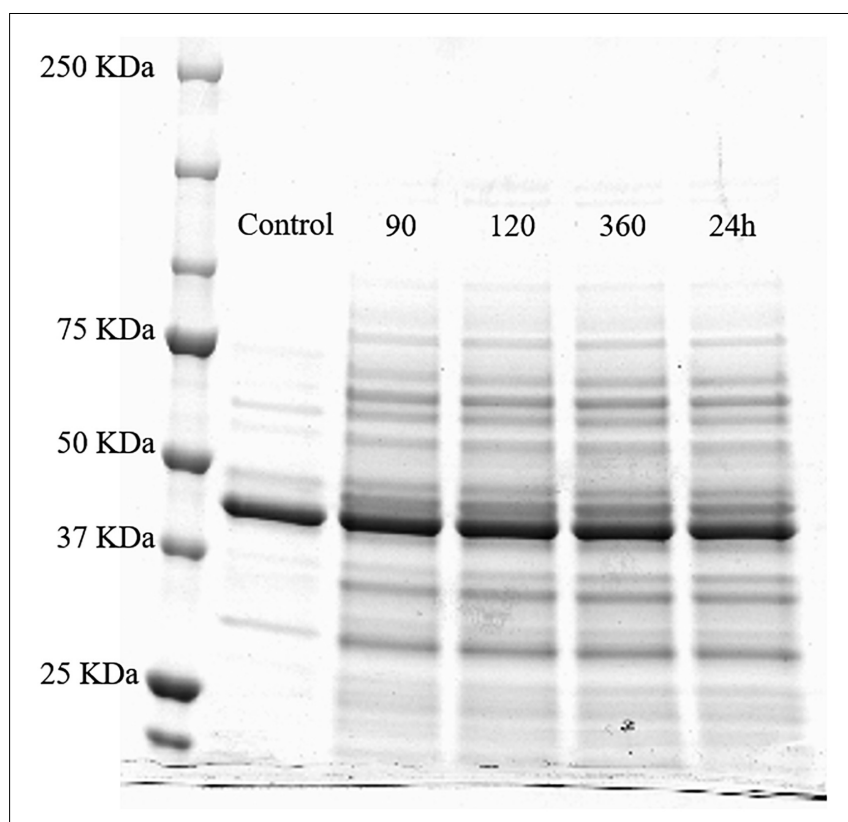

FIGURE 6 | SDS-PAGE profile of whole cell proteins $\left(500 \mu \mathrm{L} \mathrm{OD}_{600 \mathrm{~nm}}=10\right)$ of the untreated Lactobacillus acidophilus 08 (control) and HPH treated cells after 90, 120, and $360 \mathrm{~min}$, and $24 \mathrm{~h}$ upon the treatment.

particularly true when cells are subjected to 150 and $200 \mathrm{MPa}$, it becomes minimal when a reduced pressure is applied, as in our case $(50 \mathrm{MPa})$.

To better clarify the surface modifications, $\operatorname{slp} A$ gene expression was investigated. SlpA protein represents one of the three major proteins of the outermost cell envelope S-layer in L. acidophilus (Johnson et al., 2013). S-layer is a crystalline matrix of non-covalent bounded proteins (Slp proteins) that affects the surface properties of several lactobacilli including dairyfermenting and mucosal associated strains (i.e., L. acidophilus, Lactobacillus crispatus, and Lactobacillus hevleticus) (Hynönen and Palva, 2013). The $\mathrm{HPH}$ at $50 \mathrm{MPa}$ induced a strong down regulation of the $\operatorname{slp} A$ gene immediately after the treatment and during the following $120 \mathrm{~min}$ considered. However, this reduction was not associated with a decrease in $\mathrm{CSH}$, or other phenotypic traits such as autoaggregation or adherence to mucin. This could suggest that the mechanisms regulating the adhesion of L. acidophilus 08 could also be associated to a positive modification of the other outermost structure such as the cell wall and LTA. In fact, Fina Martin et al. (2019) demonstrated that LTA serves as an anchor for the S-layer protein and anchor the S-layer to the lactobacilli cell wall. Even Iucci et al. (2007) hypothesized that $\mathrm{HPH}$ treatment might induce an increased exposure of the hydrophobic regions of proteins, in relation to the level of treatment. This hydrophobicity seemed to be a key factor for the enhanced antimicrobial action of $\mathrm{HPH}$ treated enzymes such as lysozyme or lactoferrin. It has been reported that pressure can disturb the large supramolecular structure of proteins, allowing the single components to move freely, and become independent from the original structure. Interactions could be restored when the pressure instantaneously decreases, however, the original structure was not maintained because of the independent movements of the components (Iucci et al., 2007). According to Palomino et al. (2016), SlpA has a MW of $45.9 \mathrm{kDa}$ and represents $90 \%$ of the S-layer proteins in L. acidophilus ATCC 4356. In our work, the untreated cells also possessed a very thick band in SDS-PAGE that could correspond to SIpA. This band did not change upon HPH treatment. The discrepancy between gene downregulation and presumptive protein abundance is not unknown. In fact, gene expression does not always reflect the protein amount because of the various levels of regulation inside the cells (Liu et al., 2016). Moreover, in our case, the decrease observed was around $1 \mathrm{RGE}$, a value maybe not enough to be observed from a protein content point of view. Another possible hypothesis is that an S-layer-carrying bacteria could express alternative S-layer protein genes for the adaptation to stressful environmental conditions (Sára and Sleytr, 2000; JakavaViljanen et al., 2002; Schär-Zammaretti et al., 2005; GrosuTudor et al., 2016). As shown by Grosu-Tudor et al. (2016), the S-layer composition of $L$. acidophilus IBB 801 was impacted by different culturing conditions like growth temperature, osmotic pressure, and $\mathrm{pH}$. Probably, the homogenization induced a specific response passing through the activation of alternative slp genes that mediate the adaptation to the stress applied. In our work, HPH treatment increased bands between 45 and $50 \mathrm{kDa}$ that could correspond to the Slp proteins, such as SlpX. In fact, Palomino et al. (2016) observed an increase in SplX upon osmotic stress. Since these speculations are based on MW profiles, more specific analyses on S-proteins, such as westernblotting or proteomics, would be needed. Other than the putative S-layer proteins, HPH treatment determined an overall increase of bands with high and low MWs. Tabanelli et al. (2015) showed an increase of low MW peptides in the HPH treated L. acidophilus DRU using a proteomic approach by means of MALDI-TOF. The generation of these molecules was attributed both to the effect of $\mathrm{HPH}$ on the cell-surface proteins and the cellular response to $\mathrm{HPH}$ treatment. In addition, an increase in the higher MW proteins could have been the result of both de novo protein synthesis and mechanical rearrangement of the outermost cell surface following the treatment applied. The discontinuous S-layer of the treated cells and the cell wall sublethal damages observed may have exposed proteins with hydrophobic regions that enhanced cell adhesion and hydrophobicity.

\section{CONCLUSION}

High pressure homogenization applied at $50 \mathrm{MPa}$ on L. acidophilus 08 improved the $\mathrm{CSH}$ (higher $\mathrm{H} \%$ ), autoaggregation and in vitro adhesion to mucin, compared to the untreated bacteria. The technology applied at a sublethal level also induced specific modulations on the general stress response and cell adhesion genes. In particular, stress response genes groEL and ef-TU were upregulated while $c l p P$ and the $\mathrm{S}$-layer $\operatorname{slp} A$ gene were downregulated. Downregulation of $\operatorname{slp} A$ could have been compensated by a higher abundance of other Slp proteins. However, this hypothesis needs to be further studied in depth. A proteomic approach could be implemented 
to understand exactly which proteins are modulated during $\mathrm{HPH}$ treatment and to define which one could have an impact on the improved functionality. In fact, as reported by $\mathrm{Wu}$ et al. (2016), a comprehensive proteome profile of the target microbial species, when subjected to different stress, can provide a more reliable information in describing the molecular rescue strategy adopted by the strain to a specific stress. Eventually, to completely understand the entire HPH mechanism, the structure of peptidoglycan and LTAs following the HPH treatments needs to be elucidated. The results obtained in the present work may support the evidence that sublethal HPH treatments can positively affect some adhesion phenotypic traits of L. acidophilus 08 inducing a cell response between 60 and 120 min upon the treatment. Thus, the development of innovative strategies to increase strain probiotic performances by using the $\mathrm{HPH}$ technology should take into consideration the optimization of the operational protocols.

\section{REFERENCES}

Amblee, V., and Jeffery, C. J. (2015). physical features of intracellular proteins that moonlight on the cell surface. PLoS One 10:e0130575. doi: 10.1371/journal. pone. 0130575

Bergonzelli, G. E., Granato, D., Pridmore, R. D., Marvin-Guy, L. F., Donnicola, D., and Corthésy-Theulaz, I. E. (2006). GroEL of Lactobacillus johnsonii La1 (NCC 533) is cell surface associated: potential role in interaction with the host and gastric pathogen Helicobacter pylori. Infect. Immun. 74, 425-434. doi: 10.1128/iai.74.1.425-434.2006

Buck, B. L., Altermann, E., Svingerud, T., and Klaenhammer, T. R. (2005). Functional analysis of putative adhesion factors in Lactobacillus acidophilus NCFM. Appl. Environ. Microb. 71, 8344-8351. doi: 10.1128/AEM.71.12.83448351.2005

Burns, P., Vinderola, G., Binetti, A., Quiberoni, A., de Los Reyes-Gavilan, C., and Reinheimer, J. (2008). Bile-resistant derivatives obtained from non-intestinal dairy lactobacilli. Int. Dairy J. 18, 377-385. doi: 10.1016/j.resmic.2011.07.005

Burns, P. G., Patrignani, F., Tabanelli, G., Vinderola, G. C., Siroli, L., Reinheimer, J. A., et al. (2015). Potential of high pressure homogenisation on probiotic Caciotta cheese quality and functionality. J. Funct. Foods 13, 126-136. doi: 10.1016/j.jff.2014.12.037

Bury, D., Jelen, P., and Kaláb, M. (2001). Disruption of Lactobacillus delbrueckii ssp. bulgaricus 11842 cells for lactose hydrolysis in dairy products: a comparison of sonication, high-pressure homogenization and bead milling. Innov. Food Sci. Emerg. 2, 23-29. doi: 10.1016/S1466-8564(00)00039-4

Bustin, S. A., Benes, V., Garson, J. A., Hellemans, J., Huggett, J., Kubista, M., et al. (2009). The MIQE Guidelines: Minimum Information for Publication of Quantitative Real-Time PCR Experiments. Oxford: Oxford University Press, doi: 10.1373/clinchem.2008.112797

Collado, M. C., Meriluoto, J., and Salminen, S. (2008). Adhesion and aggregation properties of probiotic and pathogen strains. Eur. Food Res. Technol. 226, 1065-1073. doi: 10.1007/s00217-007-0632-x

FAO/WHO (2001). Evaluation of Health and Nutritional Properties of Powder Milk and Live Lactic Acid Bacteria. Rome: $\mathrm{FAO} / \mathrm{WHO}$.

Fina Martin, J., Palomino, M. M., Cutine, A. M., Modenutti, C. M., Fernández Do Porto, D. A., Allievi, M. C., et al. (2019). Exploring lectin-like activity of the S-layer protein of Lactobacillus acidophilus ATCC 4356. Appl. Microbiol. Biotechnol. 103, 4839-4857. doi: 10.1007/s00253-019-09795-y

Frees, D., Savijoki, K., Varmanen, P., and Ingmer, H. (2007). Clp ATPases and ClpP proteolytic complexes regulate vital biological processes in low GC, Gram-positive bacteria. Mol. Microbiol. 63, 1285-1295. doi: 10.1111/j.13652958.2007.05598.x

Gagnon, M., Berner, A. Z., Chervet, N., Chassard, C., and Lacroix, C. (2013). Comparison of the Caco-2, HT-29 and the mucus-secreting HT29-MTX

\section{DATA AVAILABILITY STATEMENT}

The original contributions presented in the study are included in the article/supplementary material, further inquiries can be directed to the corresponding author/s.

\section{AUTHOR CONTRIBUTIONS}

$\mathrm{RL}, \mathrm{GB}$, and FP designed the research, interpreted the data, and wrote the manuscript. GB and MD'A performed the research and analyzed the data. DG and LS contributed to the data interpretation. RL and FP supervised the experimental work and provided the funds. All authors contributed to revising the manuscript and approved the submitted version.

intestinal cell models to investigate Salmonella adhesion and invasion. J. Microbiol. Methods 94, 274-279. doi: 10.1016/j.mimet.2013.06.027

Gaucher, E. A., Miyamoto, M. M., and Benner, S. A. (2001). Function-structure analysis of proteins using covarion-based evolutionary approaches: elongation factors. Proc. Natl. Acad. Sci. U.S.A. 98, 548-552. doi: 10.1073/pnas.98. 2.548

Granato, D., Bergonzelli, G. E., Pridmore, R. D., Marvin, L., Rouvet, M., and Corthésy-Theulaz, I. E. (2004). Cell surface-associated elongation factor tu mediates the attachment of Lactobacillus johnsonii ncc533 (la1) to human intestinal cells and mucins. Infect. Immun. 72, 2160-2169. doi: 10.1128/iai.72.4. 2160-2169.2004

Grosu-Tudor, S.-S., Brown, L., Hebert, E. M., Brezeanu, A., Brinzan, A., Fadda, S., et al. (2016). S-layer production by Lactobacillus acidophilus IBB 801 under environmental stress conditions. Appl. Microb. Biotech. 100, 4573-4583.

Gupta, R. S. (1995). Evolution of the chaperonin families (HSP60, HSP 10 and TCP-1) of proteins and the origin of eukaryotic cells. Mol. Microbiol. 15, 1-11. doi: 10.1111/j.1365-2958.1995.tb02216.x

Hartl, F. U. (1996). Molecular chaperonins in cellular protein folding. Nature 381, 571-580.

Hernández-Alcántara, A. M., Wacher, C., Llamas, M. G., López, P., and Pérez-Chabela, M. L. (2018). Probiotic properties and stress response of thermotolerant lactic acid bacteria isolated from cooked meat products. $L W T$ 91, 249-257. doi: 10.1016/j.lwt.2017.12.063

Hynönen, U., and Palva, A. (2013). Lactobacillus surface layer proteins: structure, function and applications. Appl. Microb. Biotech. 97, 5225-5243. doi: 10.1007/ s00253-013-4962-2

Iucci, L., Patrignani, F., Vallicelli, M., Guerzoni, M. E., and Lanciotti, R. (2007). Effects of high pressure homogenization on the activity of lysozyme and lactoferrin against Listeria monocytogenes. Food Control 18, 558-565. doi: 10. 1016/j.foodcont.2006.01.005

Jakava-Viljanen, M., Åvall-Jääskeläinen, S., Messner, P., Sleytr, U. B., and Palva, A. (2002). Isolation of three new surface layer protein genes (slp) from Lactobacillus brevis ATCC 14869 and characterization of the change in their expression under aerated and anaerobic conditions. J. Bacteriol. 184, 67866795. doi: 10.1128/JB.184.24.6786-6795.2002

Jeffery, C. J. (2019). Intracellular/surface moonlighting proteins that aid in the attachment of gut microbiota to the host. AIMS Microbiol. 5, 77-86. doi: 10. 3934/microbiol.2019.1.77

Johnson, B., Selle, K., O’Flaherty, S., Goh, Y. J., and Klaenhammer, T. (2013). Identification of extracellular surface-layer associated proteins in Lactobacillus acidophilus NCFM. Microbiology 159(Pt 11):2269. doi: 10.1099/mic.0.07 0755-0

Kainulainen, V., and Korhonen, T. K. (2014). Dancing to another tuneadhesive moonlighting proteins in bacteria. Biology 3, 178-204. doi: 10.3390/ biology 3010178 
Klotz, C., O’Flaherty, S., Goh, Y. J., and Barrangou, R. (2017). Investigating the effect of growth phase on the surface-layer associated proteome of Lactobacillus acidophilus using quantitative proteomics. Front. Microbiol. 8:2174. doi: 10. 3389/fmicb.2017.02174

Kragh, K. N., Alhede, M., Rybtke, M., Stavnsberg, C., Jensen, P. Ø, TolkerNielsen, T., et al. (2018). The inoculation method could impact the outcome of microbiological experiments. Appl. Environ. Microb. 84:e02264-17. doi: 10. 1128/aem.02264-17

Lanciotti, R., Patrignani, F., Iucci, L., Saracino, P., and Guerzoni, M. E. (2007). Potential of high pressure homogenization in the control and enhancement of proteolytic and fermentative activities of some Lactobacillus species. Food Chem. 102, 542-550. doi: 10.1016/j.foodchem.2006.06.043

Lea, T. (2015). "Caco-2 cell line," in The Impact of Food Bioactives on Health, eds K. Verhoeckx, P. Cotter, I. López-Expósito, C. Kleiveland, T. Lea, A. Mackie, et al. (Cham: Springer), 103-111. doi: 10.1007/978-3-319-16104-4

Liu, Y., Beyer, A., and Aebersold, R. (2016). On the dependency of cellular protein levels on mRNA abundance. Cell 165, 535-550. doi: 10.1016/j.cell.2016.03.014

Mbye, M., Baig, M. A., AbuQamar, S. F., El-Tarabily, K. A., Obaid, R. S., Osaili, T. M., et al. (2020). Updates on understanding of probiotic lactic acid bacteria responses to environmental stresses and highlights on proteomic analyses. Compr. Rev. Food Sci. Food Saf. 19, 1110-1124. doi: 10.1111/1541-4337.12554

Morelli, L., and Capurso, L. (2012). FAO/WHO guidelines on probiotics: 10 years later. J. Clin. Gastroenterol. 46, S1-S2. doi: 10.1097/MCG.0b013e318269fdd5

Palomino, M. M., Waehner, P. M., Martin, J. F., Ojeda, P., Malone, L., Rivas, C. S., et al. (2016). Influence of osmotic stress on the profile and gene expression of surface layer proteins in Lactobacillus acidophilus ATCC 4356. Appl. Microbiol. Biotechnol. 100, 8475-8484. doi: 10.1007/s00253-016-7698-y

Patrignani, F., Burns, P., Serrazanetti, D., Vinderola, G., Reinheimer, J., Lanciotti, R., et al. (2009). Suitability of high pressure-homogenized milk for the production of probiotic fermented milk containing Lactobacillus paracasei and Lactobacillus acidophilus. J. Diary Res. 76:74. doi: 10.1017/S0022029908003828

Patrignani, F., and Lanciotti, R. (2016). Applications of high and ultra high pressure homogenization for food safety. Front. Microbiol. 7:1132. doi: 10.3389/fmicb. 2016.01132

Peng, Z., Vogel, R. F., Ehrmann, M. A., and Xiong, T. (2018). Identification and characterization of adhesion proteins in lactobacilli targeting actin as receptor. Mol. Cell Probe 37, 60-63. doi: 10.1016/j.mcp.2017.08.002

Pfaffl, M. W. (2001). A new mathematical model for relative quantification in real-time RT-PCR. Nucleic Acids Res. 29:e45. doi: 10.1093/nar/29.9.e45

Pfaffl, M. W., Tichopad, A., Prgomet, C., and Neuvians, T. P. (2004). Determination of stable housekeeping genes, differentially regulated target genes and sample integrity: BestKeeper-Excel-based tool using pair-wise correlations. Biotechnol. Lett. 26, 509-515. doi: 10.1023/B:BILE.0000019559.84305.47

Ramiah, K., van Reenen, C., and Dicks, L. (2009). Expression of the mucus adhesion gene mub, surface layer protein slp and adhesion-like factor EF-TU of Lactobacillus acidophilus ATCC 4356 under digestive stress conditions, as monitored with real-time PCR. Probiotics Antimicro. 1:91. doi: 10.1007/s12602009-9009-8

Ramiah, K., van Reenen, C. A., and Dicks, L. M. T. (2008). Surface-bound proteins of Lactobacillus plantarum 423 that contribute to adhesion of Caco-2 cells and their role in competitive exclusion and displacement of Clostridium sporogenes and Enterococcus faecalis. Res. Microbiol. 59, 470-475. doi: 10.1016/j.resmic. 2008.06.002

Saibil, H. R. (2008). Chaperonin machines in action. Curr. Opin. Struct. Biol. 18, 35-42. doi: 10.1016/j.sbi.2007.11.006

Sánchez, B., Schmitter, J. M., and Urdaci, M. C. (2009). Identification of novel proteins secreted by Lactobacillus rhamnosus GG grown in de Mann-RogosaSharpe broth. Lett. Appl. Microbiol. 48, 618-622. doi: 10.1111/j.1472-765X.2009. 02579.x

Sanders, M., and Klaenhammer, T. (2001). Invited review: the scientific basis of Lactobacillus acidophilus NCFM functionality as a probiotic. J. Dairy Sci. 84, 319-331. doi: 10.3168/jds.S0022-0302(01)74481-5

Sára, M., and Sleytr, U. B. (2000). S-layer proteins. J. Bacteriol. 182, 859-868. doi: 10.1128/JB.182.4.859-868.2000

Schär-Zammaretti, P., Dillmann, M.-L., D’Amico, N., Affolter, M., and Ubbink, J. (2005). Influence of fermentation medium composition on physicochemical surface properties of Lactobacillus acidophilus. Appl. Environ. Microbiol. 71, 8165-8173. doi: 10.1128/AEM.71.12.8165-8173.2005
Schillinger, U., Guigas, C., and Heinrich Holzapfel, W. (2005). In vitro adherence and other properties of lactobacilli used in probiotic yoghurt-like products. Int. Dairy J. 15, 1289-1297. doi: 10.1016/j.idairyj.2004.12.008

Selle, K., Goh, Y. J., Johnson, B. R., O’Flaherty, S., Andersen, J. M., Barrangou, R., et al. (2017). Deletion of lipoteichoic acid synthase impacts expression of genes encoding cell surface proteins in Lactobacillus acidophilus. Front. Microbiol. 8:553. doi: $10.3389 /$ fmicb. 2017.00553

Serrazanetti, D. I., Patrignani, F., Russo, A., Vannini, L., Siroli, L., Gardini, F., et al. (2015). Cell membrane fatty acid changes and desaturase expression of Saccharomyces bayanus exposed to high pressure homogenization in relation to the supplementation of exogenous unsaturated fatty acids. Front. Microbiol. 6:1105. doi: $10.3389 /$ fmicb.2015.01105

Shewale, R. N., Sawale, P. D., Khedkar, C., and Singh, A. (2014). Selection criteria for probiotic: a review. Int. J. Probiot. Prebiot. 9, $17-22$.

Siroli, L., Braschi, G., Rossi, S., Gottardi, D., Patrignani, F., and Lanciotti, R. (2020). Lactobacillus paracasei $\mathrm{A} 13$ and high-pressure homogenization stress response. Microorganisms 8:439. doi: 10.3390/microorganisms8030439

Spurbeck, R. R., and Arvidson, C. G. (2012). Lactobacillus gasseri surface-associated proteins inhibit Neisseria gonorrhoeae adherence to epithelial cells. Infect. Immun. 80, 3743-3743. doi: 10.1128/IAI.00789-12

Sun, Y., Zhu, D.-Q., Zhang, Q.-X., Pang, X.-H., Sun, S.-R., Liu, F., et al. (2016). The expression of GroEL protein amplified from Bifidobacterium animalis subsp. lactis KLDS 2.0603 and its role in competitive adhesion to Caco-2. Food Biotechnol. 30, 292-305. doi: 10.1080/08905436.2016.1244769

Tabanelli, G., Burns, P., Patrignani, F., Gardini, F., Lanciotti, R., Reinheimer, J., et al. (2012). Effect of a non-lethal high pressure homogenization treatment on the in vivo response of probiotic lactobacilli. Food Microbiol. 32, 302-307. doi: 10.1016/j.fm.2012.07.004

Tabanelli, G., Patrignani, F., Gardini, F., Vinderola, G., Reinheimer, J., Grazia, L., et al. (2014). Effect of a sublethal high-pressure homogenization treatment on the fatty acid membrane composition of probiotic lactobacilli. Lett. Appl. Microbiol. 58, 109-117. doi: 10.1111/lam.12164

Tabanelli, G., Patrignani, F., Vinderola, G., Reinheimer, J., Gardini, F., and Lanciotti, R. (2013). Effect of sub-lethal high pressure homogenization treatments on the in vitro functional and biological properties of lactic acid bacteria. LWT Food Sci. Technol. 53, 580-586. doi: 10.1016/j.lwt.2013.03.013

Tabanelli, G., Vernocchi, P., Patrignani, F., Del Chierico, F., Putignani, L., Vinderola, G., et al. (2015). Effects of sub-lethal high-pressure homogenization treatment on the outermost cellular structures and the volatile-molecule profiles of two strains of probiotic lactobacilli. Front. Microbiol. 6:1006. doi: 10.3389/ fmicb.2015.01006

Valeriano, V., Parungao-Balolong, M., and Kang, D. K. (2014). In vitro evaluation of the mucin-adhesion ability and probiotic potential of Lactobacillus mucosae LM 1. J. Appl. Microbiol. 117, 485-497. doi: 10.1111/jam.12539

Van den Abbeele, P., Grootaert, C., Possemiers, S., Verstraete, W., Verbeken, K., and Van de Wiele, T. (2009). In vitro model to study the modulation of the mucin-adhered bacterial community. Appl. Microbiol. Biot. 83, 349-359. doi: 10.1007/s00253-009-1947-2

Vannini, L., Lanciotti, R., Baldi, D., and Guerzoni, M. (2004). Interactions between high pressure homogenization and antimicrobial activity of lysozyme and lactoperoxidase. Int. J. Food Microbiol. 94, 123-135. doi: 10.1016/j.ijfoodmicro. 2004.01.005

Vinderola, C. G., and Reinheimer, J. A. (2003). Lactic acid starter and probiotic bacteria: a comparative "in vitro" study of probiotic characteristics and biological barrier resistance. Food Res. Int. 36, 895-904. doi: 10.1016/S09639969(03)00098-X

Wang, W., He, J., Pan, D., Wu, Z., Guo, Y., Zeng, X., et al. (2018). Metabolomics analysis of Lactobacillus plantarum ATCC 14917 adhesion activity under initial acid and alkali stress. PLoS One 13:e0196231. doi: 10.1371/journal.pone. 0196231

Weiss, G., and Jespersen, L. (2010). Transcriptional analysis of genes associated with stress and adhesion in Lactobacillus acidophilus NCFM during the passage through an in vitro gastrointestinal tract model. J. Mol. Microb. Biotech. 18, 206-214. doi: 10.1159/000316421

Wickner, S., Maurizi, M. R., and Gottesman, S. (1999). Posttranslational quality control: folding, refolding, and degrading proteins. Science 286, 1888-1893. 
Wu, Z., Pingping, W., He, J., Pan, P., Zeng, X., and Cao, J. (2016). Proteome analysis of Lactobacillus plantarum strain under cheese-like conditions. J. Proteom. 146, 165-171. doi: 10.1016/j.jprot.2016.07.008

Conflict of Interest: The authors declare that the research was conducted in the absence of any commercial or financial relationships that could be construed as a potential conflict of interest.
Copyright $\odot 2021$ Braschi, D’Alessandro, Gottardi, Siroli, Patrignani and Lanciotti. This is an open-access article distributed under the terms of the Creative Commons Attribution License (CC BY). The use, distribution or reproduction in other forums is permitted, provided the original author(s) and the copyright owner(s) are credited and that the original publication in this journal is cited, in accordance with accepted academic practice. No use, distribution or reproduction is permitted which does not comply with these terms. 